\title{
HISTORY OF THE ENVIRONMENT AND POPULATION OF THE OLD TOWN OF KLAIPĖDA, WESTERN LITHUANIA: MULTIDISCIPLINARY APPROACH TO THE LAST MILLENNIUM
}

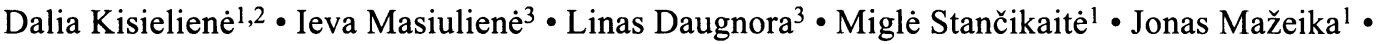 \\ Giedrè Vaikutiene் $\dot{e}^{4}$ Rimantas Petrošius ${ }^{1}$
}

\begin{abstract}
Progressive stages in the development of the Old Town region of the city of Klaipeda (in German, Memel) were ascertained by analyzing archaeological and historical data combined with an analysis of pollen, diatom, plant macrofossil, and osteological findings as cross-referenced with radiocarbon measurements. The port city of Klaipeda, located on the eastern part of the Baltic Sea, was an important political, economic, and religious center during the last millennium. In addition to its environmental history, the character of human activity and urbanization of the area during the 16th-17th centuries $\mathrm{AD}$ were examined. The chronology of these records is based on archaeological, historical, and ${ }^{14} \mathrm{C}$ data. The results obtained indicate the predominance of a wet boggy environment and the presence of a pond in the investigated territory of Klaipeda during the late 15 th and early 16 th centuries AD. The formation of a new Dane River channel created an island town, resulting in a defensible residual area for the town inhabitants. An ongoing deposition of a cultural layer began in the mid-16th century AD. Rich zooarchaeological data found in this layer provided new details on human diet and exposed a predominance of domestic animals, especially cattle. Due to intensive amelioration of this area, layers of sandy and clayey deposits were formed during the second half of the 16th century AD. A significant presence of cultivars, ruderals, and weeds were recorded, indicating substantial human activity and increasing urbanization of the landscape. According to the paleobotanical, archaeological, and historical data, the culmination of this process took place at the end of the 16th and beginning of the 17 th centuries $\mathrm{AD}$, when residential areas were established.
\end{abstract}

\section{INTRODUCTION}

An integrated multiproxy approach based on lithological, paleobotanical, zooarchaeological, and isotopic data, combined with archaeological and historical records, provides a multifaceted reconstruction of the population and landscape history of the studied site as impacted by increased levels of human activity. Compilation of archaeological, historical, and radiocarbon information is relied on in order to more accurately determine the area's chronological development, the reconstruction of which is often difficult for a variety of natural and anthropogenic reasons. Similar methodological approaches were applied in numerous other sites of the Baltic region where the urban environment of the last millennium was studied (Vuorela 1994; Vuorela et al. 1996; Latałowa 1999; Latałowa et al. 2003; Kihno and Hiie 2008; Stančikaitė et al. 2008).

Recently, multidisciplinary investigations of this nature were undertaken in the Old Town of Klaipeda in western Lithuania. Detailed archaeological excavations have been ongoing in this area for several decades, so there is now a significant accrual of archaeological data available (Žulkus 2002). However, prior to this study no systematic multiproxy investigations involving the landscape, population development, and chronological background have been performed at this site.

The aim of the present study is to reconstruct an environmental and population history of this area during the last millennium through an integrated analysis and determination of an independent chronological framework based on documentary and instrumental records. To accomplish this, ${ }^{14} \mathrm{C}$ measurements along with archaeological information, historical records, and new paleobotanical and zooarchaeological data retrieved from one of the archaeological trenches will be discussed.

\footnotetext{
${ }^{1}$ Nature Research Centre, Institute of Geology and Geography, T. Ševčenkos 13, 03223 Vilnius, Lithuania.

${ }^{2}$ Corresponding author. Email: kisieliene@geo.lt.

${ }^{3}$ Institute of History and Archaeology of the Baltic Sea Region, Klaipeda University, H Manto 84, 92294 Klaipeda, Lithuania.

${ }^{4}$ Department of Geology and Mineralogy, Vilnius University, Čiurlionio 21/27, 03101 Vilnius, Lithuania.
} 


\section{ENVIRONMENTAL SETTING}

The town of Klaipeda is located in western Lithuania. It is an ice-free port on the coast of the Baltic Sea and Curonian Lagoon (Figure 1A,B). Formed during the different stages of the Baltic Sea history, the territory later occupied by the town is rather flat except for the coastal zone, where the sandy surface has been reworked by aeolian processes, creating a picturesque landscape predominated by sandy dunes. The flat Maritime Plain formed by the Last Weichselian glaciation stretches eastwards (Guobyte் 2002). The investigated territory covers part of the historical residential blocks. It is situated within the Old Town of Klaipeda, on the left bank of the Danè River, about $700 \mathrm{~m}$ from its confluence with the Curonian Lagoon. Archaeological excavations were carried out in the site of the Kurpiu Street 3 complex of buildings and yards (Figure 1C) formed in the 16th century AD, and reconstructed a number of times in the 19th and 20th centuries AD (Masiulienè 2008, 2009a).

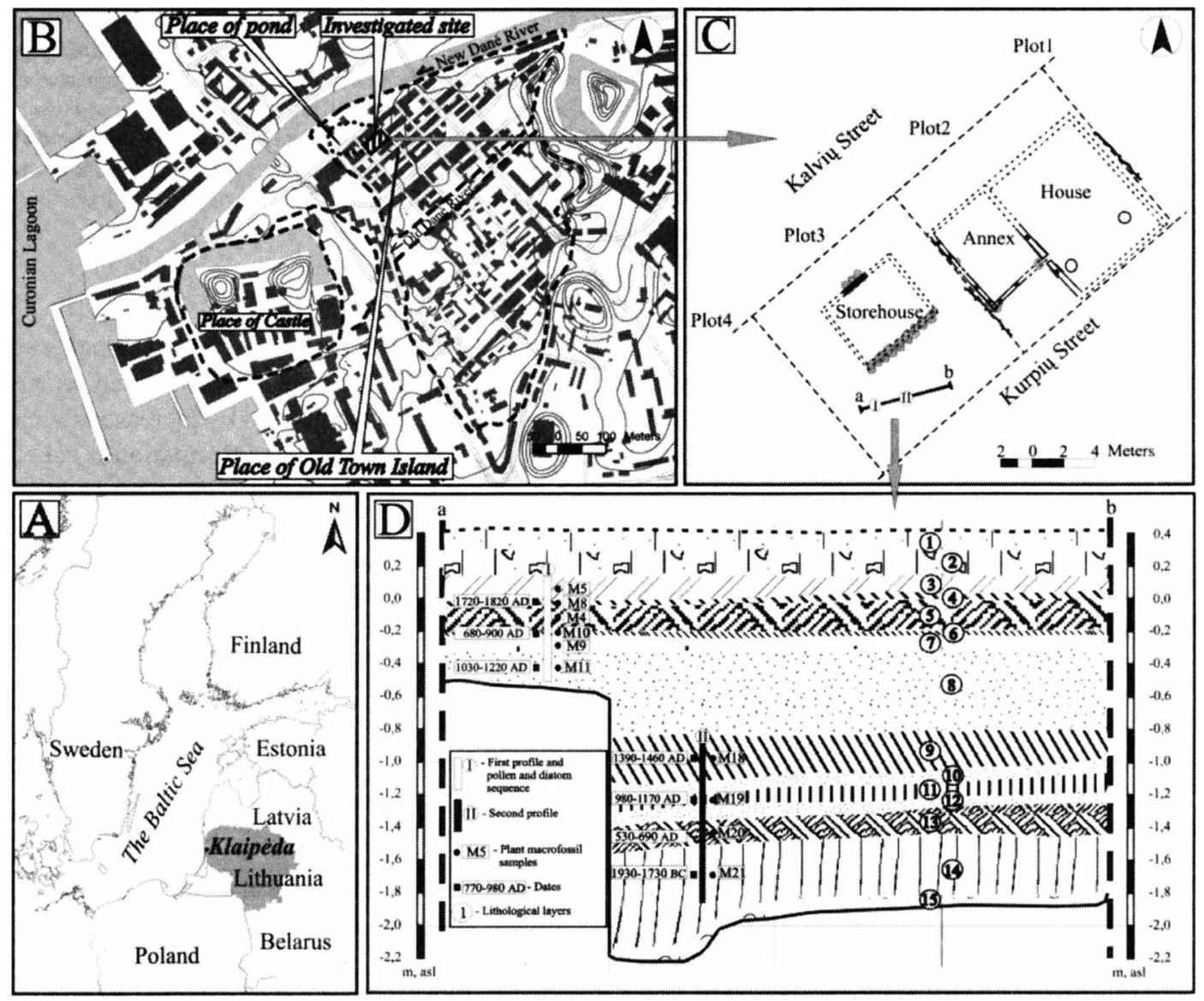

Figure 1 Location of the Klaipeda (A) and investigated site (B). Scheme of excavated plots (C) and stratigraphy of the profiles I and II with position of the samples (D). See Table 1 for the description of layers.

\section{ARCHAEOLOGICAL AND HISTORICAL BACKGROUND}

Although the earliest evidence of human presence dates back to the 1st millennium AD, significant development of the territory occurred only after the Klaipeda Castle (in German, Memelburg) was completed by the Livonian Order in 1252 (Žulkus 1994, 2001). Already in 1257-1258 due to its 
urban development, Klaipèda was granted Lübeck city rights. Nevertheless, the initial development consisted of only a small settlement surrounding the castle as well as the proximate islands located in the Dane River delta (Figure 1B). The situation changed in the beginning of the 16th century AD, when the reconstruction of the castle allowed inhabited areas in the territory of the current Old Town to expand (Figure 1B) (Žulkus 2010). At this time, a new channel of the Dané River was formed, producing the town island (Figure 1B). Although the earliest traces of economic activity in the territory of the Old Town were dated back to the late 15 th and early 16 th centuries $A D$, the actual formation of the streets and residential blocks occurred in the first half of the 16th century (Žulkus 2001). A noticeable increase in economic activity ensued when the town was granted Duke Albrecht's privilege in 1538 (Sembritzki 1926). Subsequently, new suburbs developed (in German, Ledergasse, Krammeist, Grosse Vitte, and Kleine Vitte), attracting merchants from western Europe (Tatoris 1994). Despite numerous fires that destroyed the town in 1520, 1540, 1623, and 1678 (Sembritzki 1926), Klaipeda remained the center of economic activity, trade, and religious life in this part of the Baltic.

Archaeological artifacts found in the investigated site suggest that the initial stages of human activity started in the mid-16th century here. According to the dendrochronological record (Masiuliene 2009c), the residential house in the second plot was built in AD 1542 and the annex in AD 1554 (Figure 1C). Later, storehouses were built on both plots; the buildings date from the turn of 16th17th centuries AD (Masiuliene 2009c). Unfortunately, the discovered buildings were destroyed by fire in 1678. Numerous archaeological artifacts, i.e. household items, pottery, stove tiles, structural ceramics, coins, dating from the mid-16th century to the end of the 17th century AD, were discovered in the cultural layer (Masiulienè 2008, 2009a), suggesting trading as a possible activity of the plots' owners (Masiulienè 2009c). Archaeological artifacts indicate that the residents were quite prosperous as numerous luxurious wares (i.e. brass pins, a piece of horn plate, several brass book bindings) were discovered there as well.

\section{MATERIAL AND METHODS}

\section{Lithology and Sampling}

The lithological composition of the sediment strata had been studied and described through direct observation of the trench walls, where sample columns for archaeobotanical and isotope surveys were taken in the area of the plot $3\left(55^{\circ} 42^{\prime} 31^{\prime \prime} \mathrm{N}, 21^{\circ} 07^{\prime} 56^{\prime \prime} \mathrm{E}\right.$, Figure 1C). Pollen and diatom samples were taken every $2 \mathrm{~cm}$ from vertical profile I (Figure 1D). Plant macrofossil samples covering 5-15 cm intervals were taken from the layers of 2 profiles (I and II) and a part of these samples removed for conventional ${ }^{14} \mathrm{C}$ dating. Materials for the zooarchaeological investigations were collected from the entire cultural layer during the excavation.

\section{${ }^{14} \mathrm{C}$ Dating}

Prior to conventional ${ }^{14} \mathrm{C}$ dating, samples (including organic constituent) were crushed and treated with an acid-alkali-acid (AAA) washing to remove carbonate and humic acid contamination. For benzene production, the remaining bulk organic carbon was used. Benzene output for most of samples was $0.6-1.3 \mathrm{~g}$. The specific activity of ${ }^{14} \mathrm{C}$ in benzene was measured by the liquid scintillation counting (LSC) method as described in Gupta and Polach (1985), Arslanov (1985), and Kovaliukh and Skripkin (1994), using a Tri-Carb ${ }^{\circledR} 3170 \mathrm{TR} / \mathrm{SL}$ in the Radioisotope Research Laboratory at the Nature Research Centre in Vilnius. The ${ }^{14} \mathrm{C}$ calibration program OxCal v 3.10 (Bronk Ramsey 1995, 2001) with the IntCal04 data set (Reimer et al. 2004) was used for the calibration of ${ }^{14} \mathrm{C}$ dates. All dates are given at the $1 \sigma$ confidence level and expressed in calendar years $\mathrm{BC} / \mathrm{AD}$. 


\section{Paleobotanical Analyses}

Plant macrofossils, i.e. non-carbonized plant macroremains, were extracted from sediment samples ( $350 \mathrm{~mL}$ in volume) by wet sieving on screens with mesh sizes of 0.2 and $0.5 \mathrm{~mm}$. Macrofossils were sorted and identified using a stereomicroscope at 20-100× magnification and using the identification atlases of Grigas (1986), Jacquat (1988), Latałowa (1999), Cappers et al. (2006), and a reference collection. Botanical nomenclature follows Gudžinskas (1999). Identified taxa have been arranged in broadly defined ecosociological groups (Behre and Jacomet 1991; Latałowa et al. 2003).

Diatom frustules were extracted from the sediments using conventional techniques described by Miller and Florin (1989). A total of 300 frustules from each slide were identified according to Krammer and Lange-Bertalot (1986-1991). Identified diatoms were classified into 3 ecological groups according to preferred habitats and salinity requirements (van Dam et al. 1994; Loseva et al. 2004; Barinova et al. 2006).

Subsamples of $5 \mathrm{~cm}^{3}$ were prepared for pollen analysis using a standard chemical procedure, including treating the sediments with a heavy liquid $\left(\mathrm{CdI}_{2}+\mathrm{KI}\right)$. Identification of discovered pollen grains followed Moore et al. (1991). Land-use indicator taxa followed Behre (1981), Gaillard and Berglund (1988), and Veski (1998). The percentage of pollen and diatom diagrams were produced with TILIA and TILIA-GRAPH (Grimm 1992). For each diagram, biostratigraphic zones represent a compromise between numerical analysis (CONISS) and visual inspection. Unfortunately, due to the restricted project budget, additional investigations of botanical remains, like charcoal analyses, were not applied in site.

\section{Zooarchaeological Survey}

Altogether, 270 bone samples of macrofauna representing cultural layer 9 were analyzed. The size of the bones varied from 5 to $20 \mathrm{~cm}$. Bones were identified using the collection of the Osteological Laboratory of the Lithuanian University of Health Sciences. Percentage calculations of the separated specimens were based on the total sum of identified finds.

\section{RESULTS}

\section{Lithostratigraphy}

Details of the sediment lithostratigraphy are presented in Table 1. The basal part of the sediment sequence consists of minerogenic layers (i.e. sand, clayey sand with the thin interlayers enriched by organic material, such as plant remains and peaty sand). The thickness of the cultural layer varies around $20 \mathrm{~cm}$ and is covered by $54 \mathrm{~cm}$ of sand. The upper most part of the profile, including the cultural strata, is dominated by sand, sandy soil, and clayey sand enriched by varying amounts of organic components, charcoal, and archaeological artifacts.

\section{Chronology}

The chronological framework of the site is based on $7{ }^{14} \mathrm{C}$ dates, and on archaeological and historical data. Part of the ${ }^{14} \mathrm{C}$ dates follow a stratigraphic background, though a few appear to be older than the expected age. In such a case, correlation of ${ }^{14} \mathrm{C}$ data with that obtained during the archaeological and historical investigations were determinative.

The conventional ${ }^{14} \mathrm{C}$ date representing the lowermost part of the studied sequence (layer 14) produced the date 1930-1730 cal BC (Figure 2, Table 2), corresponding to the Late Neolithic-Early Bronze Age transition in Lithuania (Brazaitis 2005). No archaeological artifacts have been discov- 
Table 1 Brief description of the sediment sequence.

\begin{tabular}{cll}
\hline Layer & Depth $(\mathrm{m}$ asl/bsl) & Lithological description \\
\hline \multicolumn{2}{l}{ Profile II } & \\
1 & $0.27-0.4$ asl & Cultural layers of 20th century \\
2 & $0.14-0.27$ asl & Silty sand with remains formed after fire of AD 1678 \\
3 & $0.01-0.14$ asl & Silty sand with brick's fragments \\
4 & 0.01 asl-0.02 bsl & Peaty soil \\
5 & $0.02-0.18$ bsl & Silty sand with burned wood \\
6 & $0.18-0.25$ bsl & Light brown sandy soil \\
7 & $0.25-0.30$ bsl & Brown sandy soil \\
8 & $0.30-0.53$ bsl & Gray sand with freshwater shells and organic \\
Profile I & \\
9 & $0.84-1.08$ bsl & Cultural layer (brown peaty soil) with artifacts (middle-end 16th c.) \\
10 & $1.08-1.12$ bsl & Gray sand \\
11 & $1.12-1.22$ bsl & Brown peaty soil with brick's fragments \\
12 & $1.22-1.30$ bsl & Gray sand with organic \\
13 & $1.30-1.44$ bsl & Interlayer of peaty sand with plant sticks (Phragmites) \\
14 & $1.44-2.10$ bsl & Peaty soil /sand \\
15 & 2.10 bsl and lower & Silty sand \\
\hline
\end{tabular}

ered in this layer, suggesting this as the natural origin of the investigated bed. The same is true regarding the chronology of the peaty sand (layer 13) and brown peaty soil (layer 11) dated back to AD 530-690 and 980-1170 respectively (Table 2). The chronology of the cultural layer (layer 9) was identified by compiling archaeological, historical, and ${ }^{14} \mathrm{C}$ information. First, the investigated area was mentioned in Duke Albrecht's privilege, dated to AD 1538 (Sembritzki 1926). Because the investigated plot was situated within this area, one could construe that the development of the urban landscape started at about 1538 here. However, the ${ }^{14} \mathrm{C}$ dating (cal AD 1390-1460, Table 2) representing this layer (9) suggests an older age of the strata. Recorded discrepancies may have occurred due to the presence of the older material in the investigated sample as intensive amelioration of the territory including transportation of the sediments was mentioned in the historical sources (Masiulienè 2008). On the other hand, presence of the earlier human interference in the area cannot be dismissed either. The latter fact was confirmed by the written sources indicating existence of a garden in the territory of the town island in 1504 (Sembritzki 1926). Formation of the sediment layers 6, 7 , and 8 was related with the amelioration of the territory that took place between AD 1542 and 1570 (Masiuliene 2008). For this reason, a remarkable amount of the sediments were transported into the area and this fact was confirmed by the historical data (Masiulienè 2008, 2009b). On the other hand, results of ${ }^{14} \mathrm{C}$ dating show the investigated sediments deposited at about cal AD 1030-1220 and 680-900 and are significantly older than the expected date. The older dating of the investigated sediments can be explained as indicating the age of the material transported into the area and not related with the chronology of the layers itself. Archaeological and ${ }^{14} \mathrm{C}$ data shows that the formation of the upper part of sequence continued during the 17th-18th centuries AD.

\section{Archaeobotanical Investigations}

The pollen record indicated a few stages in the history of the vegetation cover. On the basis of visual inspection and statistical analysis, 3 local pollen assemblage zones (LPAZ) have been established (Figure 3). In the diatom diagram, 3 local diatom assemblage zones (LDAZ) were determined (Figure 4). Some 64 plant taxa and 1002 plant specimens were recorded from 2 investigated profiles (Figure 1D). Table 3 shows an overview of the distribution and grouping of the taxa. 


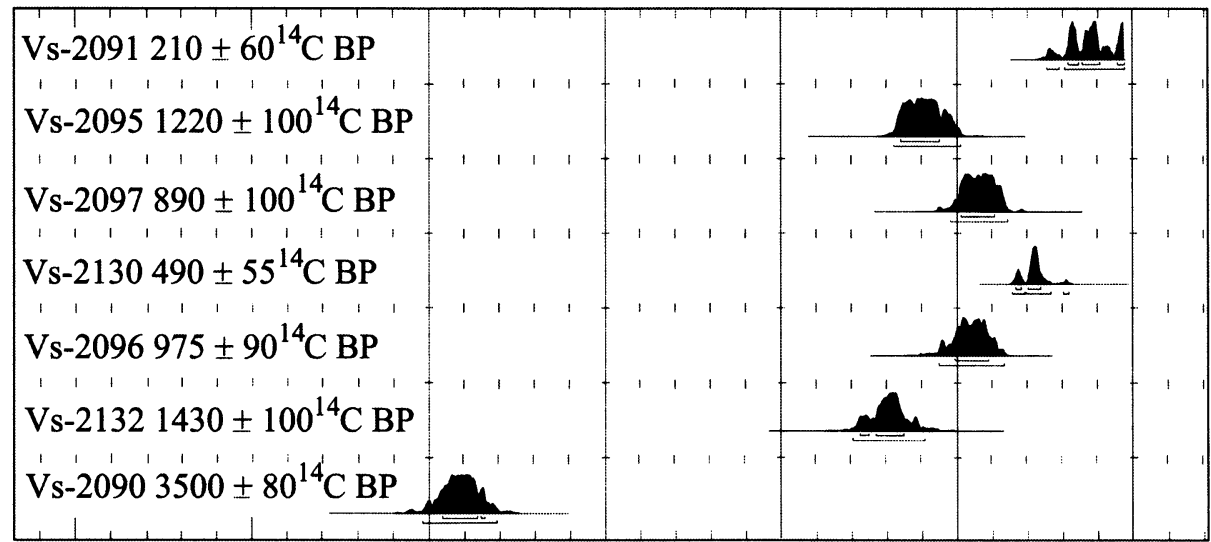

4000 CalBC 3000 CalBC 2000 CalBC 1000 CalBC CalBC/CalAD 1000 CalAD 2000 CalAD Calibrated date

Figure $2{ }^{14} \mathrm{C}$ data from the excavated site

Table 2 Radiocarbon dates from Kurpių Street 3.

\begin{tabular}{|c|c|c|c|c|c|c|}
\hline $\begin{array}{l}\text { Lab } \\
\text { code } \\
\text { (Vs-) }\end{array}$ & $\begin{array}{l}\text { Sediment layer / sam- } \\
\text { pling interval alti- } \\
\text { tude, m asl or bsl/ } \\
\text { dated fraction }\end{array}$ & $\begin{array}{l}\text { Archaeo- } \\
\text { logical } \\
\text { context }\end{array}$ & $\begin{array}{l}\mathrm{C}_{\text {org }}(\%) \text { in } \\
\text { material af- } \\
\text { ter AAA } \\
\text { treatment }\end{array}$ & $\begin{array}{l}\delta^{13} \mathrm{C}_{\text {org }} \\
\text { (\%o PDB) }\end{array}$ & $\begin{array}{l}\text { Reservoir- } \\
\text { corrected } \\
{ }^{14} \mathrm{C} \text { age }(\mathrm{BP})\end{array}$ & $\begin{array}{l}\text { Calibrated age range } \\
(1 \sigma)\end{array}$ \\
\hline 2091 & $\begin{array}{l}\text { Layer } 4 / 0.01-0.02 \mathrm{~m} \\
\text { asl / pretreated bulk } \\
\text { organic material }\end{array}$ & $\begin{array}{l}\text { Near the } \\
\text { storehouse }\end{array}$ & 21.7 & -28.1 & $210 \pm 60$ & $\begin{array}{l}\text { AD } 1640-1700(20.9 \%) \text {; } \\
\text { AD } 1720-1820(35.0 \%) \\
\text { AD } 1920-1960(12.3 \%)\end{array}$ \\
\hline 2095 & $\begin{array}{l}\text { Layer } 6 / 0.18-0.25 \mathrm{~m} \\
\text { bsl / pretreated bulk } \\
\text { organic material }\end{array}$ & $\begin{array}{l}\text { Near the } \\
\text { storehouse }\end{array}$ & 0.7 & -28.3 & $1220 \pm 100$ & AD $680-900(68.2 \%)$ \\
\hline 2097 & $\begin{array}{l}\text { Layer } 8 / 0.40-0.45 \mathrm{~m} \\
\text { bsl / pretreated bulk } \\
\text { organic material }\end{array}$ & $\begin{array}{l}\text { Near the } \\
\text { storehouse }\end{array}$ & 0.7 & -28.4 & $890 \pm 100$ & AD $1030-1220(68.2 \%)$ \\
\hline 2129 & $\begin{array}{l}\text { Layer } 9 \text { / } 0.85 \mathrm{~m} \mathrm{bsl} / \\
\text { pretreated bulk or- } \\
\text { ganic material }\end{array}$ & $\begin{array}{l}\text { Near the } \\
\text { house }\end{array}$ & 1.0 & -28.3 & $490 \pm 55$ & $\begin{array}{l}\text { AD } 1320-1350(7.3 \%) \\
\text { AD } 1390-1460(60.9 \%)\end{array}$ \\
\hline 2096 & $\begin{array}{l}\text { Layer } 11 / 1.16 \mathrm{~m} \mathrm{bsl} / \\
\text { pretreated bulk or- } \\
\text { ganic material }\end{array}$ & $\begin{array}{l}\text { Near the } \\
\text { house }\end{array}$ & 1.2 & -28.6 & $975 \pm 90$ & AD $980-1170(68.2 \%)$ \\
\hline 2132 & $\begin{array}{l}\text { Layer } 13 / 1.36 \mathrm{~m} \mathrm{bsl} / \\
\text { pretreated bulk or- } \\
\text { ganic material }\end{array}$ & Onshore & 3.2 & -28.4 & $1430 \pm 100$ & $\begin{array}{l}\text { AD } 440-490(8.2 \%) \\
\text { AD } 530-690(60.0 \%)\end{array}$ \\
\hline 2090 & $\begin{array}{l}\text { Layer } 14 / 1.60 \mathrm{~m} \mathrm{bsl} / \\
\text { pretreated bulk or- } \\
\text { ganic material }\end{array}$ & $\begin{array}{l}\text { Pond } \\
\text { shoreline }\end{array}$ & 30.3 & -28.5 & $3500 \pm 80$ & $\begin{array}{l}1930-1730 \text { BC }(65.1 \%) \\
1710-1690 \text { BC }(3.1 \%)\end{array}$ \\
\hline
\end{tabular}

\section{Results of Zooarchaeological Survey}

Zooarchaeological analysis identified by species 199 of the 270 discovered bones and bone fragments. The remains of domestic animals, i.e. cattle, pigs, sheep/goats, predominate in the investigated material. Some of the identified wild animal bone fragments, including elk and red deer, and single fragments of roe deer, hare, and possibly a boar, suggest that a part of the townspeople's diet consisted of game meat as well. 


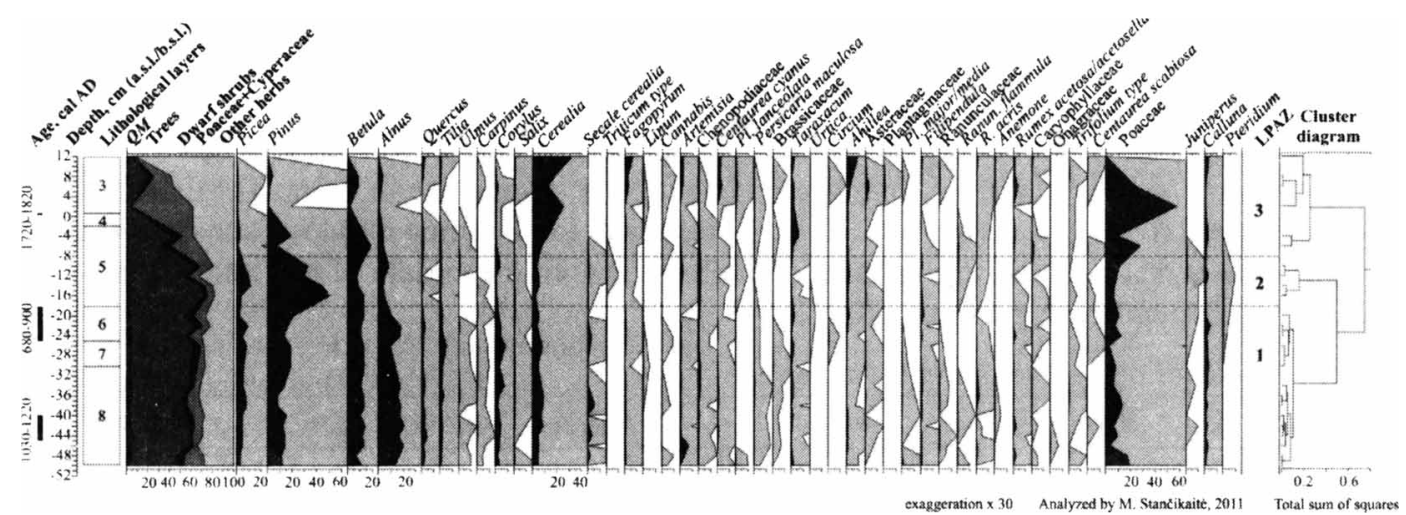

Figure 3 Percentage pollen diagram for selected taxa from profile II

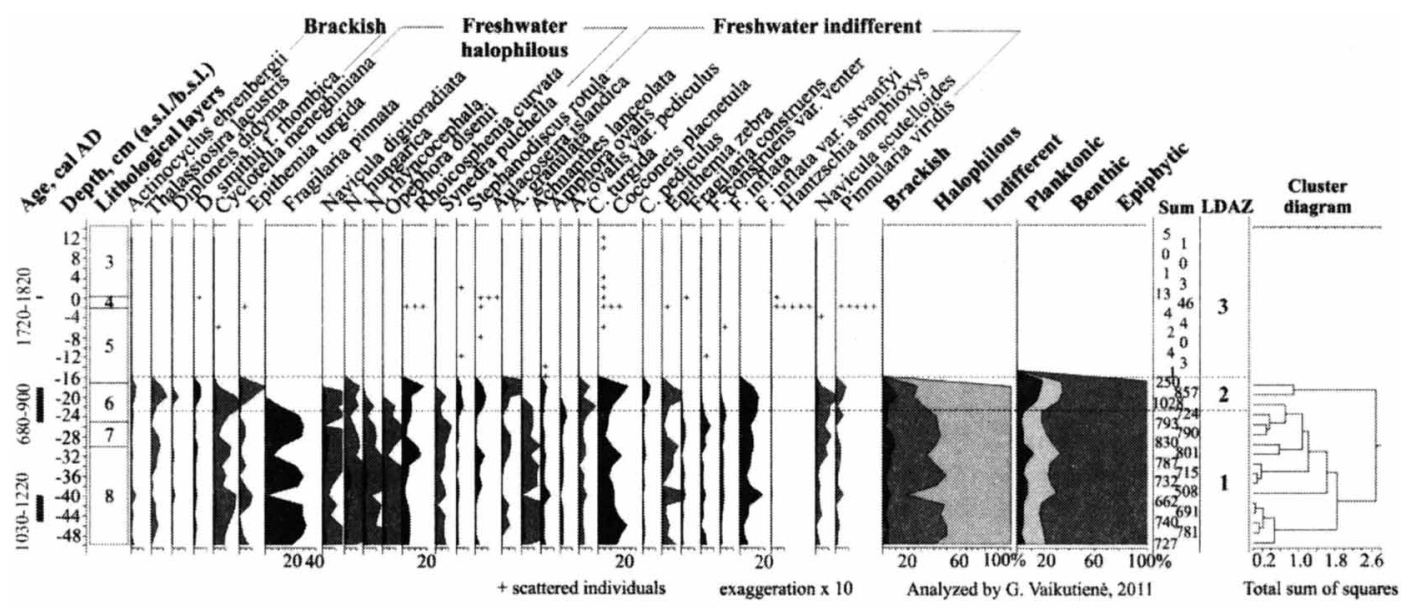

Figure 4 Percentage diatom diagram for selected taxa from profile II

\section{DISCUSSION}

This study provided new information on the chronological features and evolution of the landscape in this section of the Old Town of Klaipeda. Being situated near the mouth of the Dane River, the investigated territory has been influenced by numerous external forces, such as changes in the water level of the Baltic Sea and Curonian Lagoon (Gelumbauskaite 2009), fluvial processes, and human interference. Evidently, natural forces prevailed during the earliest stages of the site's development, when the lowermost part of the profile II was formed. Formation of a peaty and silty sand (layer 14), dating back to 1930-1730 cal BC (Table 1), suggests intensive fluvial processes. Only scattered plant macroremains were discovered in this bed (Table 3). The archaeobotanical remains were preserved to a greater degree and were more diversified in the sediment layers 13 and 11 deposited at the turn of 1st-2nd millennium AD. Remnants of shallow water (Potamogeton and Myriophyllum) and litoral zone (Carex, Ranunculus, and Sparganium) as well as those typical for muddy shorelines (Ranunculus sceleratus, Elatine hydropiper, and Juncus spp.) predominated in these layers. The lithological composition of the above-mentioned beds suggests changes in sedimentation regime, i.e. fluvial processes were accompanied by the lacustrine ones leading to the formation of the oxbow lake that later developed into the water pond, the existence of which was noted in historical documents (Sembritzki 1926). Nevertheless, floods continued to be an important factor in the site's 
development; sandy interlayers were recorded in the investigated profile (layers 12 and 10). Although the Klaipèda Castle was situated close to area under investigation since 1252 (Žulkus 2010), no archaebotanical or archaeological finds confirming human activity were recorded in the investigated plot. Only a few diaspores of several species such as Urtica dioica, Polygonum aviculare, Persicaria lapathifolia, and Rumex acetosella that may originate from ruderals or field habitats were discovered (layer 11). However, these taxa are typical for the damp meadows and riversides as well. It appears that the area was damp and uninhabited until the middle of the 16th century AD when intensive population growth began.

Table 3 Results of plant macroremains analysis.

\begin{tabular}{|c|c|c|c|c|c|c|c|c|c|c|}
\hline Profile & & & & II & & & & the & I & \\
\hline Archaeological layer & 3 & 4 & 5 & 6 & 7 & 8 & 9 & 11 & 13 & 14 \\
\hline Sample nr & M5 & M8 & M4 & M10 & M9 & M11 & M18 & M19 & M20 & M21 \\
\hline Cultural plants, sum & 1 & & & & & & 1 & & & \\
\hline Ficus carica $\mathrm{L}$. & & & & & & & 1 & & & \\
\hline Hyssopus officinalis L. & 1 & & & & & & & & & \\
\hline Weeds of cereals and flax, sum & 1 & 19 & & & & & 2 & & & 1 \\
\hline Agrostemma githago L. & & 4 & & & & & & & & \\
\hline Fallopia convolvulus (L.) A.Love & 1 & 5 & & & & & 1 & & & \\
\hline Galeopsis tetrahit $\mathrm{t}$. & & 9 & & & & & 1 & & & 1 \\
\hline Spergulla arvensis L. & & 1 & & & & & & & & \\
\hline $\begin{array}{l}\text { Weeds of millet, gardens, and ruderal } \\
\text { habitats, sum }\end{array}$ & 18 & 71 & 3 & 8 & 8 & 17 & 59 & 20 & 9 & 2 \\
\hline Brassica napus L. & & 2 & & & & & & & & \\
\hline Chenopodium album $\mathrm{L}$. & 6 & 5 & & 2 & 1 & 4 & 9 & 1 & 2 & \\
\hline Chenopodium polyspermum $\mathrm{L}$. & 2 & 10 & & & 3 & 3 & 2 & & & \\
\hline Cirsium arvense (L.) Scop. & & 3 & & & & & & & & \\
\hline Mentha arvensis $\mathrm{L}$. & & 3 & 1 & & & & 2 & 1 & & 1 \\
\hline Persicaria lapathifolia (L.) Gray & 2 & 17 & & 3 & 2 & 1 & 13 & 2 & & \\
\hline Polygonum aviculare $\mathrm{L}$. & 2 & 3 & & & & 3 & 3 & 7 & & \\
\hline Potentilla anserina $\mathrm{L}$. & 2 & 4 & 1 & & & 1 & 1 & 3 & & \\
\hline Ranunculus repens $\mathrm{L}$. & & 2 & & & & & & & & \\
\hline Rumex acetosella $\mathrm{L}$. & 4 & 13 & 1 & 2 & & 3 & 15 & 2 & 1 & \\
\hline Stellaria media (L.) Vill. & & & & & & & 3 & & & \\
\hline Sonchus cf. arvensis L. & & 4 & & & & & & & & \\
\hline Thlaspi arvense L. & & 5 & & & & & & & & \\
\hline $\begin{array}{l}\text { Urtica dioica } \mathrm{L} . \\
\text { Urtica urens } \mathrm{L} .\end{array}$ & & & & 1 & 2 & 2 & $\begin{array}{l}8 \\
3\end{array}$ & 4 & 6 & 1 \\
\hline Dry grasslands and pastures, sum & $\mathbf{0}$ & 2 & 1 & 2 & 2 & 2 & 5 & 2 & $\mathbf{0}$ & $\mathbf{0}$ \\
\hline Carex pallescens $\mathrm{L}$. & & & & 2 & & & 5 & & & \\
\hline Hypericum perforatom $\mathrm{L}$. & & & & & 1 & & & & & \\
\hline Picris hieracioides $\mathrm{L}$. & & 1 & & & & & & & & \\
\hline Potentilla argentea $\mathrm{L}$. & & & 1 & & & 2 & & & & \\
\hline Silene nutans L. & & 1 & & & & & & & & \\
\hline Trifolium repens $\mathrm{L}$. & & & & & 1 & & & 2 & & \\
\hline $\begin{array}{l}\text { Wetlands, meadows in wet and fresh } \\
\text { habitats, sum }\end{array}$ & 26 & 123 & 6 & 24 & 91 & $\mathbf{5 0}$ & 159 & 60 & 38 & 18 \\
\hline Calamagrostis canescens (F.H.Wigg.) & & 1 & & & & & & & & \\
\hline Roth & & & & & & & & & & \\
\hline Carex spp. & 14 & 36 & 6 & 10 & 6 & 15 & 62 & 9 & 20 & 18 \\
\hline
\end{tabular}


Table 3 Results of plant macroremains analysis. (Continued)

\begin{tabular}{|c|c|c|c|c|c|c|c|c|c|c|}
\hline Profile & & & & II & & & & & I & \\
\hline Archaeological layer & 3 & 4 & 5 & 6 & 7 & 8 & 9 & 11 & 13 & 14 \\
\hline Sample nr & M5 & M8 & M4 & M10 & M9 & M11 & M18 & M19 & M20 & M21 \\
\hline Centaurea jacea $\mathrm{L}$. & & 2 & & & & & & & & \\
\hline Comarum palustre $\mathrm{L}$. & & 1 & & & 1 & & & & & \\
\hline Elatine hydropiper L. & & & & 9 & 76 & 17 & & 5 & & \\
\hline Eleocharis palustris (L.) Roem. et Schult. & & 1 & & & & 2 & 8 & 12 & 4 & \\
\hline Filipendula ulmaria (L.) Maxim. & & 3 & & & & & & & & \\
\hline Juncus spp. & & & & 1 & & 3 & 18 & 9 & & \\
\hline Linum catharticum $\mathrm{L}$. & 2 & 14 & & & 1 & & 4 & & & \\
\hline Lychnis flos-cuculi $\mathrm{L}$. & 1 & 1 & & & & & & & & \\
\hline Mentha aquatica $\mathrm{L}$. & 1 & & & & & & & & & \\
\hline Menyanthes trifoliata $\mathrm{L}$. & & & & & 1 & & & & & \\
\hline Poa palustris $\mathrm{L}$. & & 1 & & & & & & & & \\
\hline Potentilla erecta (L.) Raeuschel & & 9 & & & & 1 & 9 & & & \\
\hline Prunella vulgaris L. & 5 & 33 & & 1 & & 2 & 5 & 1 & & \\
\hline Ranunculus acris L. & 2 & 9 & & & 2 & 6 & 8 & & 1 & \\
\hline Ranunculus flammula $\mathrm{L}$. & 1 & 6 & & 1 & 1 & 2 & 27 & & 2 & \\
\hline Ranunculus sceleratus L. & & & & 2 & & 2 & 9 & 12 & & \\
\hline Schoenoplectus lacustris (L.) Palla & & 1 & & & 1 & & 1 & 11 & 4 & \\
\hline Scirpus sylvaticus L. & & 1 & & & 1 & & 8 & 1 & 4 & \\
\hline Sparganium sp. & & 1 & & & & & & & 3 & \\
\hline Trichophorum alpinum (L.) Pers. & & 3 & & & & & & & & \\
\hline Typha latifolia $\mathrm{L}$. & & & & & 1 & & & & & \\
\hline Aquatic plants, sum & $\mathbf{0}$ & $\mathbf{0}$ & $\mathbf{0}$ & 29 & 16 & 21 & 4 & 31 & 9 & $\mathbf{0}$ \\
\hline Alisma plantago-aquatica $\mathrm{L}$. & & & & & & 1 & 1 & 1 & 1 & \\
\hline Batrachium sp. & & & & 9 & 8 & 14 & 2 & 2 & & \\
\hline Chara sp./Nitella sp. & & & & & & & & 27 & & \\
\hline Hippuris vulgaris L. & & & & 1 & 1 & & 1 & & & \\
\hline Myriophyllum spicatum L. & & & & 2 & & & & & 1 & \\
\hline Potamogeton friesii Rupr. & & & & 14 & 2 & 3 & & & 1 & \\
\hline Potamogeton natans L. & & & & & & & & 1 & 4 & \\
\hline Potamogeton pectinatus $\mathrm{L}$. & & & & & & & & & 2 & \\
\hline Zannichellia palustris $\mathrm{L}$. & & & & 3 & 5 & 3 & & & & \\
\hline Forests, glades, and clearings, sum & 1 & $\mathbf{0}$ & $\mathbf{0}$ & 3 & $\mathbf{0}$ & 5 & 17 & 1 & 14 & $\mathbf{0}$ \\
\hline $\begin{array}{l}\text { Alnus glutinosa }(\mathrm{L} .) \text { Gaertn } \\
\text { Betula sect. Albae }\end{array}$ & & & & 1 & & & & & 10 & \\
\hline Corylus avellana $\mathrm{L}$. & 1 & & & & & & & & 3 & \\
\hline Fragaria vesca $\mathrm{L}$. & & & & 1 & & 4 & 10 & 1 & 1 & \\
\hline Rubus idaeus L. & & & & 1 & & 1 & 7 & & & \\
\hline Total sum & 47 & 215 & 10 & 66 & 117 & 95 & 247 & 114 & 70 & 21 \\
\hline
\end{tabular}

According to historical and archaeological data, the inhabited areas expanded to the territory of the current Old Town of Klaipeda during the first half of the 16th century AD (Žulkus 2001). Plant macroremains (sample M 18) discovered in the cultural layer (layer 9) indicate a predominance of wetland flora where buttercups and sedges were in abundance and the number of water plants declined. These changes may have been occasioned by the amelioration undertaken when increased human activity coincided with the formation of a new Dane River channel and town island and the subsequent infilling of the pond (Masiuliene 2009b). Open grasslands, small pastures, and gardens 
existed in the area during the initial stages of its residential development. The presence of a cabbage garden in the area of the town island was noted in historical sources in 1504 (Sembritzki 1926). Furthermore, weeds and ruderals flourished on these plots according to the plant macrofossil data. The scattered finds of cereal weeds have been identified, suggesting the transportation and storage of surplus grains. Storehouses dating to the second half of the 16 th and beginning of 17 th centuries AD may have been primarily used for these purposes. During this time, both wild and domestic animals were transported to this area. Though remains of domestic animals, especially cattle, predominated in the zooarchaeological material, bone fragments of wild species suggest that they were used by the local population as well. Moreover, meat was one of the main export products at that time (Sembritzki 1926; Willoweit 1969; Groth 1995).

Besides the increasing human interference, a large-scale transformation of the area took place between 1542 and 1570 and was related to the extensive amelioration that was initiated in this area (Masiulienè 2008, 2009b). According to historical data, a remarkable amount of material was transported and deposited at the site, thus forming layers $8,7,6$, and 5 . The bulk of organic carbon extracted from the sediments was formed during the turn of the 1st-2nd millennium AD as indicated by ${ }^{14} \mathrm{C}$ measurements (Table 2). Evidently, all paleobotanical remains discovered in these beds represent the same time interval. Data from the diatom samples (layers 7 and 8) suggests these sediments may have accumulated in the shallow freshwater basin where freshwater halophilous (Fragilaria pinnata, Rhoicosphenia curvata) and freshwater indifferent diatoms (Cocconeis placentula, $F$. brevistriata) prevailed. Otherwise, the continuous presence of the diatoms typical for the brackish environment suggests a possible link with the sea or lagoon. This becomes especially conspicuous in layer 6. A similar sedimentation environment was reconstructed where water (Potamogeton friesii and Zannichellia palustris) and wetland (Carex sp. and E. hydropiper) taxa predominated. The occurrence of Urtica dioica, Persicaria lapathifolia, and Chenopodium album macroremains, representing apophytes of nitrophylous habitats or ruderal settings as well as damp meadow and riverside locales (Latałowa 1999), correlate well with the derived pollen data. Pollen diagrams indicate the existence of an open environment coincident with strong human presence. Cerealia, Linum usitatissimum, and Fagopyrum together with some particular weeds like Centaurea cyanus and ruderals, i.e. Artemisia and Persicaria maculosa, are widely represented in the pollen spectra, suggesting the existence of barren fields, waste ground, and settled territories (Behre 1981; Gaillard and Berglund 1988). All this evidence appears to indicate that in situ accumulation of the sediments occurred in the basin related with the Danè River and situated in the closest vicinities to the Klaipeda Castle, the main center of human activity in the area since the onset of the 2 nd millennium AD (Žulkus 2002). Finally, the probability that intensive human interference and the formation of an urban landscape started in the surrounding territories earlier than the existing chronology shows needs further investigation.

A gray clayey bed with burned wood (layer 5) caps the described sandy layers and separates the upper dry and the lower wet parts of the sequence. Both the diatoms and the plant macroremains are represented by the scattered finds here. Meanwhile, the pollen data suggests the existence of the open habitats that may include urban areas and meadows. Moreover, the pollen curves of anthropogenic indicators ruderals and weeds gradually begin to rise.

The culmination of human activity was recorded in layers 4 and 3, which date back to AD 1570 1678 according to archaeological and historical data (Masiulienè 2008, 2009c). The flourishing of Poaceae in the pollen spectra suggests the formation of extensive grasslands in the barren areas, ruderal plots, and other artificial habitats that may have occurred along the Dane River. Furthermore, the recorded sudden decay of the tree curves reflects rapid expansion of the urban areas as recorded 
both in archaeological and historical sources (Masiuliene 2009b,c). Although the occurrence of cereals and weeds recorded in plant macrofossil and pollen spectra suggests intensive agricultural activity in the area, the simultaneous formation of the urban landscape would contradict such a conclusion. The transportation and subsequent storage of harvested grains as confirmed by archaeological data could reconcile this apparent contradiction. The accumulated data suggests the formation of a nearly treeless urban environment characterized by a significant presence of agricultural products such as cereals and hay. Growth of the site ended in AD 1678 when the urban block was destroyed by fire (Masiulienè 2009c). The uppermost part of the investigated profile (layers 1 and 2) were formed later (Masiulienè 2008).

\section{CONCLUSIONS}

The multiproxy archaeobotanical record from the Old Town of Klaipeda, together with the ${ }^{14} \mathrm{C}$, archaeological, and historical information, provides new data about the environment and population history in this part of Klaipeda during the 2 nd millennium AD. Macrobotanical data suggest the formation of a shallow oxbow lake near the turn of 1st-2nd millennium AD here. Later, the lake transformed into a pond. Until the middle of the 16th century, natural factors such as fluvial and lacustrine processes predominated in the development of the site. New paleoenvironmental and archaeological information places the onset of increased human activity during the middle of the 16th century $\mathrm{AD}$, when the inhabited areas expanded to the territory of the current Old Town of Klaipeda. At that time, significant landscape transformations occurred, including the formation of a new Dane River channel and the resultant town island, providing inhabitants with additional land. The wet, boggy landscape was gradually replaced with open grasslands, small pastures, and/or gardens consisting of typical plant communities. The second half of the 16th century AD produced the formation of the residential blocks and subsequent urbanization of the area. The growing population was sustained by the production of crops and meat, which was supplied by domestic animals, especially cattle. Increasing human interference was accompanied by the extensive amelioration of the territory and the infilling of the above-mentioned pond between AD 1542 and 1570. The age, origin, and archaeobotanical records of the infilling material needs to be investigated further since the data obtained suggests that intensive human interference as well as the formation of the urban landscape of the surrounding territories occurred earlier than shown by the existing chronology. After the reclamation of the territory in the late 16th and early 17 th centuries $A D$, open habitats that may have included extensive grasslands in the barren areas, ruderal plots, and other artificial habitats gain even more ground. Furthermore, the rapid expansion of the urban areas was recorded both in archaeological and historical sources, suggesting intensive exploitation of the land and formation of the highly urban landscape.

\section{ACKNOWLEDGMENTS}

This study was financed by the Research Council of Lithuania (No. LEK-02/2010).

\section{REFERENCES}

Arslanov KhA. 1985. Radiocarbon: Geochemistry and Geochronology. Leningrad. In Russian.

Barinova SS, Medvedeva LA, Anissimova OV. 2006. Diversity of Algal Indicators in Environmental Assessment. Tel Aviv: Pilies Studio Publishing House.

Behre KE. 1981. The interpretation of anthropogenic indicators in pollen diagrams. Pollen et Spores 23:22545 .
Behre KE, Jacomet S. 1991. The ecological interpretation of archaeobotanical data. In: van Zeist W, Wasylikowa K, Behre KE, editors. Progress in Old World Palaeoethnobotany. Rotterdam: Balkema. p 81-108.

Brazaitis Dž. 2005. Ankstyvasis metalu laikotarpis [The Early Metal period]. In: Girininkas A, editor. Lietuvos istorija I. Akmens amžius ir ankstyvasis metalu laikotarpis. Vilnius: Baltos Lankos. p 251-318. 
Bronk Ramsey C. 1995. Radiocarbon calibration and analysis of stratigraphy: the OxCal program. Radiocarbon 37(2):425-30.

Bronk Ramsey C. 2001. Development of the radiocarbon calibration program. Radiocarbon 43(2A):355-63.

Cappers RTJ, Bekker RM, Jans JEA. 2006. Digital Seed Atlas of the Netherlands. Groningen: Barkhius Publishing \& Groningen University Library.

Gaillard MJ, Berglund BE. 1988. Land-use history during the last 2700 years in the area of Bjäresjö, southern Sweden. In: Birks H, Birks HJB, Kaland PE, Moe D, editors. The Cultural Landscape: Past, Present and Future. Cambridge: Cambridge University Press. p 409-28.

Gelumbauskaitè LŽ. 2009. Character of sea level changes in the subsiding south-eastern Baltic Sea during Late Quaternary. Baltica 22(1):23-36.

Grigas A. 1986. Lietuvos augalu vaisiai ir sèklos [Fruits and Seeds of Lithuanian Plants]. Vilnius: Mokslas.

Grimm EC. 1992. TILIA and TILIA-GRAPH: PC spreadsheet and graphics program. In: 8th International Palynological Congress. Program and $A b-$ stracts. Aix-en-Provence, France.

Groth A. 1995. Żegluga i handel morski Ktajpedy $w$ latach 1664-1722. Statystyka obrotu towarowego [Shipping and Marine Trade in Klaipeda in the Years 1664-1722. Statistics of Commodities]. Gdańsk.

Gudžinskas Z. 1999. Lietuvos induočiai augalai [Vascular Plants of Lithuania]. Vilnius: Institute of Botany.

Guobytė R. 2002. Lithuanian surface: geology, geomorphology and deglaciation [abstract of PhD dissertation]. Vilnius. $31 \mathrm{p}$.

Gupta SH, Polach HA. 1985. Radiocarbon Practices at $A N U$, Handbook. Canberra: Australian National University.

Jacquat Ch. 1988. Hauterive-Champréveyres, 1. Les plantes de l'âge du Bronze. Catalogue des fruits et graines. Archéologie neuchâteloise 7. Saint-Blaise: Editions du Ruau.

Kihno K, Hiie S. 2008. Evidence of pollen and plant macroremains from the sediments of suburban area of medieval Tartu. Estonian Journal of Archaeology 12(1): $30-50$.

Kovaliukh NN, Skripkin VV. 1994. An universal technology for oxidation of carbon-containing materials for radiocarbon dating. In: Abstracts and Papers of Conference on Geochronology and Dendrochronology of Old Town's and Radiocarbon Dating of Archaeological Findings. Vilnius, Lithuania, 31 October-4 November. Vilnius: Vilnius University Press. p 37-42.

Krammer K, Lange-Bertalot H. 1986-1991. Süßwasserflora von Mitteleuropa. 2(1-4). Bacillariophyceae. Stuttgart/Jena: VEB Gustav Fischer Verlag.

Latałowa M. 1999. Palaeoecological reconstruction of the environmental conditions and economy in the early medieval Wolin-against a background of the Holocene history of the landscape. Acta Palaeobotanica 39(2):183-271.
Latałowa M, Badura M, Jarosinska J. 2003. Archaeobotanical samples from non-specific urban contexts as a tool for reconstructing environmental conditions (examples from Elblag and Kołobrzeg, northern Poland). Vegetation History and Archaeobotany 12:93-104.

Loseva EI, Stenina AS, Marchenko-Vagapova TI. 2004. Cadastre of the Fossil and Recent Diatoms from Northeastern Europe. Syktyvkar: Geoprint.

Masiulienè I. 2008. Tyrinèjimai Kurpių g. 3 [Studies in Kurpių Street 3]. In: Archeologiniai tyrinèjimai Lietuvoje 2007 metais. Vilnius: Lietuvos archeologijos draugija. p 341-54.

Masiulienè I. 2009a. Sklypas Kurpių g. 3 [Plot of Kurpiu Street 3]. In: Archeologiniai tyrinèjimai Lietuvoje 2008 metais. Vilnius: Lietuvos archeologijos draugija. p 345-53.

Masiulienè I. 2009b. Klaipèdos senamiesčio šiaurès vakarinès dalies raida XVI-XVII amžiais [Development of the northwestern part of Klaipeda Old Town in the XVI-XVII c.]. Lietuvos Archeologija 35:24158.

Masiulienè I. 2009c. 16th-17th cen. Klaipeda town residents' lifestyle (by archaeological, palaeobotanical and zooarchaeological data of Kurpių street plots). $\mathrm{Ar}$ chaeologia Baltica 12:95-111.

Miller U, Florin MB. 1989. Diatom analysis. Introduction to methods and applications. Geology and palaeoecology for archaeologists. PACT 24:133-57.

Moore PD, Webb JA, Collinson ME. 1991. Pollen Analysis. Oxford: Blackwell.

Reimer PJ, Baillie MGL, Bard E, Bayliss A, Beck JW, Bertrand CJH, Blackwell PG, Buck CE, Burr GS, Cutler KB, Damon PE, Edwards RL, Fairbanks RG, Friedrich M, Guilderson TP, Hogg AG, Hughen KA, Kromer B, McCormac G, Manning S, Bronk Ramsey C, Reimer RW, Remmele S, Southon JR, Stuiver M, Talamo S, Taylor FW, van der Plicht J, Weyhenmeyer CE. 2004. IntCal04 terrestrial radiocarbon age calibration, 0-26 cal kyr BP. Radiocarbon 46(3):1029-58.

Sembritzki J. 1926. Geschichte der Königlich Preussischen See- und Handelsstadt Memel. Memel.

Stančikaitė M, Kisielienė D, Mažeika J, Blaževičius P. 2008. Environmental conditions and human interference during the 6 th and 13 th-15th centuries A.D. at Vilnius Lower Castle, east Lithuania. Vegetation History and Archaeobotany 17(1):239-50.

Tatoris J. 1994. Senoji Klaipéda, Urbanistinè raida ir architektūra iki 1939 metu [The Old Klaipeda, Urban Development and Architecture until 1939]. Vilnius: Mokslo ir enciklopediju leidykla.

van Dam H, Mertens A, Sinkeldam J. 1994. A code checklist and ecological indicator values of freshwater diatoms from the Netherlands. Netherlands Journal of Aquatic Ecology 28(1):117-33.

Veski S. 1998. Vegetation history, human impact and palaeogeography of western Estonia. Pollen analytical studies of lake and bog sediments. Striae 38:1-119.

Vuorela I. 1994. Palynological investigations in the old 
town of Helsinki. Bulletin of the Geological Society of Finland 66(2):125-8.

Vuorela I, Grönlund T, Lempiäinen T. 1996. A reconstruction of the environment of retting in the city of Turku, Finland, on the basis of diatom, pollen, plant macrofossil and phytolith analyses. Bulletin of the Geological Society of Finland 68(2):46-71.

Willoweit G. 1969. Die Wirtschaftsgeschichte des Memellandes. I-II. Marburg/Lahn.

Žulkus V. 1994. Klaipèdos istorijos ir topografijos bruožai XIII-XVII a. (archeologijos duomenimis) [Historical and topographical features of the Klaipèda in XIII-XVII centuries (according to archaeological data)]. Acta Historica Universitatis Klaipedensis 2:514.

Žulkus V. 2001. Die Hausbau in Klaipeda (Memel). In: Lübecker Kolloquium zur Stadtarchäologie im Hanseraum III: Der Hausbau. Lübeck: SchmidtRömhild. p 529-49.

Žulkus V. 2002. Viduramžių Klaipèda, Miestas ir pilis, Archeologija ir istorija [Medieval Klaipeda, City and Castle, Archaeology and History]. Vilnius: Žara.

Žulkus V. 2010. Die Stadtbefestigungen von Klaipèda (Memel). In: Lübecker Koolloquium zur Stadtarchäologie im Hanseraum VII: Die Befestigungen. Lübeck: Schmidt-Römhild. p 653-67. 